Лютий P. В.

Аналітичний метод розрахунку теплових полів литих деталей під час кристалізації

\author{
Liutyi R.
}

\title{
Analytical method of calculation of thermal fields of cast parts during crystallization
}

Метою роботи є створення математичної методики, яка дає змогу розраховувати розподіп теппових полів у литих деталях під час кристалізації за допомогою системи аналітичних формул.

Під час розрахунків використано поєднання відомих аналітичних формул Г.Ф. Баландіна, А. Й. Вейника, С. Шварца із власними оригінальними математичними рішеннями, створеними на основі аналізу теплофьізичних процесів у виливках в процесі їх кристалізації. Для порівняння результатів застосовано комп'ютерне моделювання теплових полів за допомогою програми «LVMFlow».

За створеною математичною методикою наведено приклади розрахунку теплових полів для двох виливків із сталі 25Л порожнистої циліндричної фоорми, товщина стінок яких становить 100 мм і 4 мм відповідно. Розрахунки проведено для умов кристалізації виливків у разовій піщаній формі. Представлено порівняння результатів розрахунків за розробленим методом і з використанням існуючого програмного забезпечення.

Вперше на основі власних математичних і теплофрізичних розробок розроблено комплексну розрахункову методику визначення теплового поля виливка під час кристалізації та охолодження, яка заснована на встановленні кінетики охолодження поверхні виливка у ливарній формі, просування фронту кристалізації від поверхні до центру виливка, розподілу температур у твердій та рідкій частинах виливка. Методика виражена у ряді аналітичних формул, кожна із яких описує конкретний тепловий процес, який відбувається у виливку. При цьому враховано особливості конфрігурації виливка.

Створений комплексний метод розрахунку теплових полів литих деталей є математичною основою для визначення теплових полів ливарних форм і стрижнів, що дає змогу прогнозування їх властивостей та вибору оптимальних формувальних матеріалів. Також створену методику може бути запропоновано як математичну основу для уточнення прикладних комп'ютерних програм з ливарного виробництва.

ВИЛИВОК, ТЕМПЕРАТУРА, ТЕПЛОВЕ ПОЛЕ, ДИНАМІКА ОХОЛОДЖЕННЯ, ТРИВАЛІСТЬ ОХОЛОДЖЕННЯ, МАТЕМАТИЧНИЙ ЗАКОН, ФРОНТ ТВЕРДІННЯ, РОЗРАХУНОК

The aim of the work is to create a mathematical method that allows to calculate the distribution of thermal fields in cast parts during crystallization using a system of analytical formulas.

During the calculations, a combination of known analytical formulas GF was used. Balandin, AY Weinik, S. Schwartz with their own original mathematical solutions created on the basis of the analysis of thermophysical processes in castings in the process of their crystallization. Computer simulation of thermal fields using the LVMFlow program was used to compare the results.

According to the created mathematical method, examples of calculation of thermal fields for two castings made of steel $25 \mathrm{~L}$ of hollow cylindrical shape, the wall thickness of which is $100 \mathrm{~mm}$ and $4 \mathrm{~mm}$, respectively, are given. Calculations were performed for the conditions of crystallization of castings in a single sand form. The comparison of results of calculations by the developed method and with use of the existing software is presented.

For the first time, based on our own mathematical and thermophysical developments, a comprehensive calculation method for determining the thermal field of the casting during crystallization and cooling was developed. casting. The technique is expressed in a number of analytical formulas, each of which describes a specific thermal process that occurs in the casting. This takes into account the features of the casting configuration.

The created complex method of calculation of thermal fields of cast parts is a mathematical basis for determining the thermal fields of molds and rods, which allows to predict their properties and select the optimal molding materials. The created technique can also be offered as a mathematical basis for refining applied computer programs for foundry production.

CASTING, TEMPERATURE, THERMAL FIELD, COOLING DYNAMICS, COOLING DURATION, MATHEMATICAL LAW, COLORING FRONT, CALCULATION

\section{Аналіз літературних даних та постановка проблеми.}

Основною метою математичних розрахунків у ливарному виробництві $є$ отримання системи раціональних теоретичних уявлень і аналітичних методів, які дають змогу з необхідною для практичних цілей точністю розраховувати параметри технологічного процесу лиття [1].

Першим кроком у вирішенні математичних задач щодо розподілу теплових полів був розраху- нок промерзання ґрунту, виконаний у 1890 р. І. Стефраном [2]. Він установив, що збільшення товщини затверділого шару пропорційно квадратному кореню із часу, і цю закономірність неодноразово підтверджено в подальшому [1-4]. У 20-х рр. XX ст. C. Саїто [5] вперше вирішив теплову задачу стосовно металу, що твердіє, і врахував виділення теплоти кристалізації. На початку 30-х рр. XX ст. С. Шварц вперше установив приблизні формули для розрахунку розподілу температур по перерізу

Liutyi Rostislav - - Ph.D., Assoc. Prof. National Technical University of Ukraine "Igor Sikorsky Kyiv Polytechnic Institute" 
виливка і ливарної форми. Залежності побудовано на основі інтегралу ймовірності Гаусса. Зараз указана система рівнянь називається формулами Стефрана - Шварца [1-3, 6].

Надалі способи розрахунку удосконалювали за допомогою внесення додаткових параметрів і уточнення коефіцієнтів. До середини XX ст. було виконано розрахунки просування фрронту твердіння всередині виливка, а А.Й. Вейник запропонував приблизну формулу для визначення розподілу температур у його затверділій частині [2, 7]. Проте вона базується на емпіричних коефіцієнтах.

Авторами [9] запропоновано аналітичні формули для визначення температури поверхні виливка та розподілу температур у ньому, які по суті $€$ інтерпретацією метода Стефана - Шварца. Температура поверхні виливка вважається постійною та незалежною від часу.

Просування фронту кристалізації з урахуванням області твердіння (інтервалу ліквідус - солідус) розраховано А. Г. Спасським і А. А. Рижиковим у 1967-1969 рр. [2].

Г. Ф. Баландін узагальнив інформацію щодо раніше проведених розрахунків та доповнив ії власними розробками, на основі чого створив аналітичні формули для визначення тривалості твердіння і охолодження виливків у разових (неметалевих) ливарних формах. Ці формули покладено в основу більшості сучасних розрахункових методів та програмного забезпечення ливарних процесів.

Аналіз накопиченого досвіду з позицій математики і теплофізики показав, що кожен із наведених вище методів розрахунку обов'язково містить раціональне зерно. Проте жоден із них не можна назвати універсальним - таким, що дає повну картину реального розподілу теплових полів всередині виливка.

Вважається, що комп'ютерні програми моделювання ливарних процесів «MAGMASOFT», «ProCAST», «WinCAST», «LVMFlow», «NovaFlow», «Полігон» [1] дають необхідну точність теплових розрахунків, проте це не зовсім так. Теоретичне вивчення процесів перенесення тепла із відповідним складанням математичних моделей, які максимально точно відтворюють сутність процесів, практично зупинилося з появою обчислювальної техніки. Але основні теплові задачі на той момент не було остаточно вирішено. Аналітичних рішень для розподілу теплового поля в металевому розплаві і виливку в процесі затвердіння і подальшого охолодження так і не знайдено.

Як правило, програми побудовано на методах кінцевих елементів або кінцевих різниць [10-17]. Однак ці методи потребують точного завдання граничних умов, однією з яких знову $є$ температура поверхні виливка. Крім того, потрібно установити закон її зміни у часі, що жоден із існуючих методів не дає можливості зробити. Тому і комп'ютерні програми, які описують температурні поля, не дають достатньо точних результатів.

Що стосується достатньої точності, у ливарному виробництві більшість розрахунків $€$ приблизними, і це пов'язано із багатофакторністю процесів. Тому забезпечити точність розрахунку на рівні 1,0 К, або ще більшу, не тільки не представляється можливим, але й абсолютно недоцільно для реальних умов. 3 іншого боку, якщо розглядається процес у температурних межах 1700...1800 К, то навіть при досить точному розрахунку із довірчою ймовірністю 0,95 похибка може становити 85...90 К. Така зміна температури матеріалу значною мірою впливає на його властивості, але вона залишається неврахованою.

Усі чисельні методи дають вирішення тільки за умови введення спрощень [7, 8, 10-17]. Першим поширеним спрощенням $є$ прийняття змінної фрізичної величини за константу. Другим - введення у розрахунок двох або більшої кількості взаємозалежних величин. У розрахунках теплових полів поширені обидва вказаних недоліки, що пояснюється математичною невизначеністю системи.

\section{Мета і завдання дослідження.}

Метою роботи $є$ створення математичної методики, яка дає змогу розраховувати розподіл теплових полів у литих деталях під час кристалізації за допомогою системи аналітичних формул.

Під час вирішення враховано те, що сплав кристалізується в інтервалі температур (ліквідус - солідус).

Оригінальні математичні рішення, представлені у цій статті, у кінцевому підсумку мають прикладний характер. Створення методу розрахунку теплових полів виконано на реальних прикладах

Об'єктом розрахунку №1 $є$ циліндричний сталевий виливок зовнішнім діаметром $250 \mathrm{mм}$ із центральним отвором діаметром 50 мм, який виконано ливарним стрижнем (рис. 1, а). Цей виливок відноситься до товстостінних.

Об'єктом розрахунку №2 є циліндричний сталевий виливок зовнішнім діаметром $24 \mathrm{Mm}$ із центральним отвором діаметром 16 мм, який також виконано ливарним стрижнем (рис. 1, б). Цей виливок відноситься до тонкостінних.

Вихідні дані для розрахунків: вуглецева сталь 3 0,25\% C; температура заливання $\mathrm{T}_{\text {зал }}=1873 \mathrm{~K}$; температура ліквідусу $\mathrm{T}_{л}=1770 \mathrm{~K}$; температура солідусу $\mathrm{T}_{\mathrm{c}}=1720 \mathrm{~K}$; теплоємність сплаву у рідкому стані $\mathrm{C}_{\mathrm{p}}=922$ Дж/(кг $\cdot$ К); густина сплаву у рідкому стані $\rho_{p}=7000$ кг/м³; теплоакумулювальна здатність ливарної форми $\mathrm{b}_{\phi}=1630 \mathrm{Bт} \cdot \mathrm{c}^{1 / 2} /\left(\mathrm{M}^{2} \cdot \mathrm{K}\right)$; коефіцієнт температуропровідності сплаву у рідкому стані $\mathrm{a}_{\mathrm{p}}=0,95 \cdot 10^{-5}$ $\mathrm{m}^{2} / \mathrm{c}$; коефріцієнт теплопровідності сплаву у рідкому стані $\lambda_{p}=23,3 \mathrm{BT} /(\mathrm{M} \cdot \mathrm{K})$, у твердому стані $\lambda_{\mathrm{T}}=54,5$ $\mathrm{BT} /(\mathrm{M} \cdot \mathrm{K})$. 


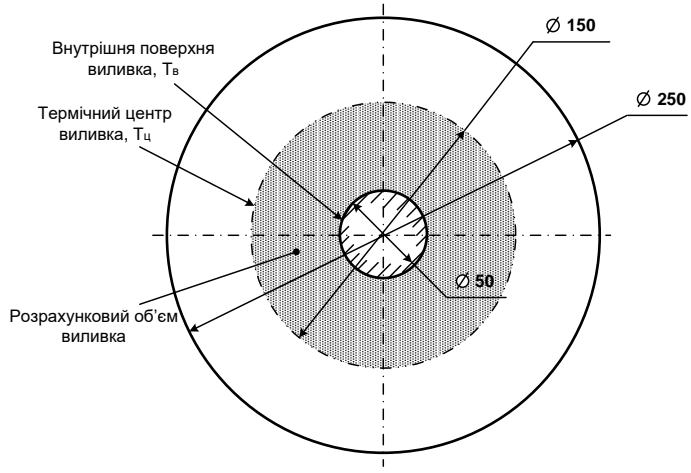

a

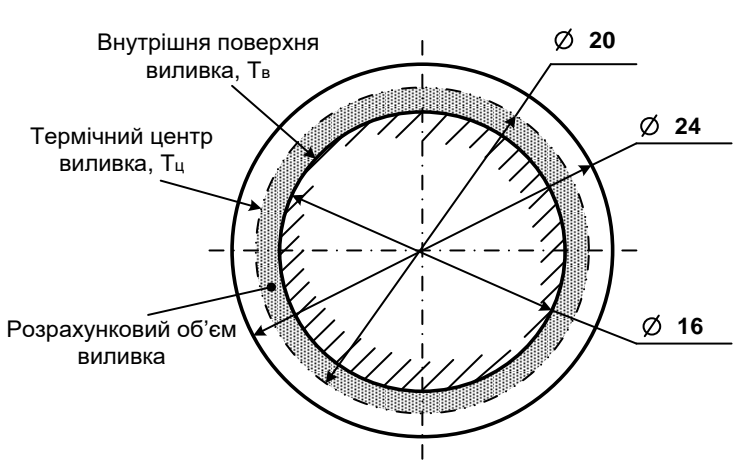

6

Рисунок 1 - Розрахункові схеми товстостінного (а) і тонкостінного (б) порожнистих сталевих виливків із внутрішніми стрижнями

Результати досліджень.

Встановлення аналітичного закону охолодження поверхні виливка.

Тривалість повного твердіння обох виливків (об'єкт №1 і об'єкт №2) розраховано за відомими формулами Г. Ф. Баландіна [2, 3]. Для товстостінного виливка діаметром 250 мм тривалість твер- діння становить 2024 с, для тонкостінного виливка діаметром 24 мм тривалість твердіння 3,5 с.

Для визначення аналітичного рівняння зміни температури поверхні виливка потрібно мати достовірну інформацію про ії значення у певні моменти часу. Для цього використано відому формулу [3] для визначення тривалості відведення теплоти перегрівання:

$$
\tau_{\text {ПЕР }}=\left[\frac{C_{p} \cdot \rho_{p} \cdot R_{3 в} \cdot\left(T_{\text {зал }}-T_{Л}\right)}{1,128 \cdot b_{\Phi} \cdot\left(T_{\text {зал }}-T_{\Phi}\right)}\right]^{2},
$$

де $\mathrm{C}_{\mathrm{p}}$ - теплоємність сплаву у рідкому стані, Дж/(кг $\cdot$ К ); $\rho_{p}$ - густина сплаву у рідкому стані, $\kappa \kappa / \mathrm{M}^{3} ; \mathrm{R}_{3 в}$ - зведений розмір виливка, м; $\mathrm{T}_{\text {зал }}, \mathrm{T}_{\text {л }}$, $\mathrm{T}_{\phi}$ - температури заливання сплаву, ліквідусу, форми, K; $\mathrm{b}_{\phi}$ - теплоакумулювальна здатність ливарної форми $\mathrm{BT} \cdot \mathrm{c}^{1 / 2} /\left(\mathrm{M}^{2} \cdot \mathrm{K}\right)$;

Розрахунок за формулою (1) показав, що для товстостінного виливка $\tau_{\text {ПЕР }}=135 c$, а для тонкостінного $\tau_{\text {ПЕР }}=0,22 c$. Тривалість відведення теплоти перегрівання з фізичної точки зору - це період, за який розплав у формі охолоджується з початкової температури (1873 К у момент часу т = 0) до початку утворення твердої фази. Оскільки кристалізація виливка починається від поверхні і закінчується у його центрі, очевидно, що у момент $\mathrm{T}=\mathrm{T}_{\text {пеР }}$ безпосередньо на поверхні виливка значення температури дорівнює $\mathrm{T}_{\mathrm{r}}=1770 \mathrm{~K}$.

Також очевидно, що застосовувати фрормулу (1) для визначення тривалості охолодження виливка нижче температури ліквідусу некоректно, тому що в об'ємі виливка з моменту т = ТПЕР Починається виділення прихованої теплоти кристалізації, а не тільки зниження температури, чого фрормула не враховує.

Розрахуємо тривалість охолодження поверхонь обох виливків до температури солідусу (1720 К) з температури заливання 1873 К. Для цього необхідно установити математичний закон охолодження поверхонь.
Постановка цієї задачі для товстостінного виливка наступна:

- початкова температура $\mathrm{T}_{0}=1873 \mathrm{~K}$;

- температура в момент часу

$\tau_{\text {IЕP }}=135 \mathrm{c}=2,25 \times 8 .: \mathrm{T}_{1}=\mathrm{T}_{\text {л }}=1770 \mathrm{~K}$;

- температура форми $\mathrm{T}_{\Phi}=293 \mathrm{~K}$;

- температура солідусу $\mathrm{T}_{2}=\mathrm{T}_{\mathrm{c}}=1720 \mathrm{~K}$.

Швидкість охолодження $v$ визначимо наступною залежністю:

$$
v=\frac{d\left(T-T_{\Phi}\right)}{d \tau} ; \frac{d T}{d \tau}=k \cdot\left(T-T_{\Phi}\right)
$$

Звідси:

$$
\begin{aligned}
& \frac{d T}{T-T_{\Phi}}=k \cdot d \tau ; \ln \left(T-T_{\Phi}\right)=k \cdot \tau+\ln C ; \\
& \frac{\ln \left(T-T_{\Phi}\right)}{C}=k \cdot \tau ;
\end{aligned}
$$

Закон охолодження поверхні матиме вигляд:

$$
T-T_{\Phi}=C \cdot e^{k \cdot \tau} .
$$

Перша гранична умова: $\mathrm{T}_{\mathrm{T}=0}=\mathrm{T}_{0}=1873 \mathrm{~K}$; $\mathrm{T}_{\Phi}=293$ К. Отже:

$$
1873-293=C \cdot 1 ; \mathrm{C}=1580 .
$$

Тоді:

$$
T-293=1580 \cdot e^{k \cdot \tau} \text {. }
$$

Друга гранична умова: $\mathrm{T}_{\mathrm{T}=2,25 \times в}=\mathrm{T}_{1}=1770 \mathrm{~K}$. Отже: 


$$
\begin{aligned}
& 1770-293=1580 \cdot e^{k \cdot 2,25} . \\
& e^{2,25 \cdot k}=0,935 . \\
& e^{k}=(0,935)^{\frac{1}{2,25}}=0,935^{0,444} .
\end{aligned}
$$

Таким чином, установлено математичний закон охолодження поверхні товстостінного виливка:

$$
T-293=1580 \cdot 0,935^{0,444 \cdot \tau} \text {. }
$$

де т - час, хв; Т - температура поверхні виливка у розрахунковий момент часу, К.

Знайдемо за формулою (3) тривалість охолодження поверхні виливка до температури солідусу $(1720 \mathrm{~K})$ :

$$
\begin{aligned}
& \mathrm{T}=\mathrm{T}_{2}=1720 \mathrm{~K} . \\
& 1720-293=1580 \cdot 0,935^{0,444 \cdot \tau} . \\
& \ln 1427=\ln 1580+0,444 \cdot \tau \cdot \ln 0,935 ; \\
& 7,26=7,37-0,03 \cdot \tau ; \\
& \tau=\frac{7,37-7,26}{0,03}=3,67 x 8=220 c .
\end{aligned}
$$

Аналогічно проведено постановку задач і вирішення диференційного рівняння охолодження для поверхні тонкостінного виливка. Установлений математичний закон охолодження має наступний вигляд:

$$
T-293=1580 \cdot 0,935^{4,545 \cdot \tau} \text {. }
$$

де т - час, с; Т - температура поверхні виливка у розрахунковий момент часу, К.

Тривалість охолодження до температури солідусу (1720 К) за формулою (4) становить 0,35 с.

Таким чином, для товстостінного виливка (рис. 1, а) встановлено наступне:

- у момент т = 0 в усіх точках (на поверхні та у термічному центрі) виливка температура $\mathrm{T}_{\mathrm{B}}=\mathrm{T}_{ц}=$ $\mathrm{T}_{\text {зал }}=1873 \mathrm{~K}$;

- у момент $\tau_{\text {ПЕР }}=135 c$ на поверхні виливка температура $\mathrm{T}_{\mathrm{B}}=1770 \mathrm{~K}$;

- у момент $\tau_{C}=220 c$ на поверхні виливка температура $\mathrm{T}_{\mathrm{B}}=1720 \mathrm{~K}$;

- за формулою (3) можна визначити температуру поверхні $\mathrm{T}_{\text {в }}$ у будь-який момент часу в період від 0 до 220 с.

Для тонкостінного виливка (рис. 1, б) встановлено наступне:

- у момент т = 0 в усіх точках (на поверхні та у термічному центрі) виливка температура $\mathrm{T}_{\mathrm{B}}=\mathrm{T}_{ц}=$ $\mathrm{T}_{\text {зал }}=1873 \mathrm{~K}$;

- у момент $\tau_{\text {ПЕP }}=0,22 c$ на поверхні виливка температура $\mathrm{T}_{\mathrm{B}}=1770 \mathrm{~K}$;

- у момент $\tau_{C}=0,35 c$ на поверхні виливка температура $\mathrm{T}_{\mathrm{B}}=1720 \mathrm{~K}$;
- за фрормулою (4) можна визначити темпера-

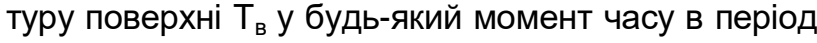
від 0 до 0,35 с.

\section{Розрахунок просування фрронту твердіння у виливках. \\ Збільшення товщини затверділого шару у товс-} тостінному виливку відбувається починаючи $3 \mathrm{~T}_{\mathrm{C}}=$ 220 c і до моменту $\tau_{T}=2024 c$. За період $(2024-220)=1804$ с товщина цього шару збільшується з 0 до 50 мм, тобто доходить до половини товщини стінки (або термічного центру) виливка.

У тонкостінному виливку наростання твердого шару відбувається починаючи з $\mathrm{T}_{\mathrm{C}}=0,35$ с до моменту $\tau_{T}=3,5 c$. За період $(3,5-0,35)=3,15$ с товщина шару збільшується з 0 до 2 мм, тобто також досягає термічного центру виливка.

Якщо би виливки були плоскими, абсолютна товщина твердого шару збільшувалася би у точній відповідності до закону «квадратного кореня». Але виливки циліндричні, і тому необхідно враховувати їх форму. Із зовнішньої поверхні виливка буде спостерігатися поступове прискорення цього процесу при просуванні від шарів виливка з більшим діаметром до шарів із меншим діаметром. Із внутрішньої поверхні виливка, тобто з боку стрижня, процес буде уповільнюватися, оскільки кількість теплоти, яку виділяє кожний подальший шар виливка, більша порівняно із попереднім.

Виходячи із викладених особливостей, розрахунок просування фронту кристалізації слід віднести не до товщини затверділого шару, а до його об'єму.

Режим просування фронту твердіння всередину виливка завжди відповідає закону «квадратного кореня» [18]. Тоді:

$$
\delta_{y T}=K_{X} \cdot \sqrt{\left(\tau-\tau_{C}\right)}
$$

де $\delta_{у т}$ - умовна товщина затверділого шару (для плоского виливка дорівнює реальній товщині), м; КХ - коефіцієнт, який відображає швидкість просування фрронту твердіння, $\frac{M}{c^{1 / 2}} ;$ т - розрахунковий момент часу, с; т - тривалість охолодження поверхні до температури солідусу, с.

Для пошуку коефіцієнтів Кх скористаємося формулою (5), прийнявши $\overline{y т}_{\text {с }}=\mathrm{R}_{\text {зв }}$ (зведений розмір або модуль охолодження виливка) а т $=\mathrm{T}_{\mathrm{T}}$ (тривалість повного твердіння).

Для товстостінного виливка:

$$
K_{X}=\frac{R_{3 в}}{\sqrt{\tau_{T}-\tau_{C}}}=\frac{0,05}{\sqrt{2024-220}}=0,001177 \frac{\mathcal{M}}{c^{1 / 2}} .
$$

Для тонкостінного виливка:

$$
K_{X}=\frac{R_{36}}{\sqrt{\tau_{T}-\tau_{C}}}=\frac{0,002}{\sqrt{3,5-0,35}}=0,001127 \frac{\mathcal{M}}{c^{1 / 2}} .
$$


Значення цього коефіцієнта для виливків відрізняються менше ніж на 5\%. Логічно слід припустити, що коефіцієнти просування фрронту твердіння для обох виливків мають однакові значення, а отримана відмінність пов'язана із округленнями під час розрахунків.

Для врахування циліндричної форми виливків виконано математичні дії у наступній послідовносTi:

- визначено розрахунковий об'єм виливків (див. рис. 1, а, б);

- визначено умовну товщину затверділого шару бут для ряду послідовних моментів часу за фрормулою (5);

- визначено відносну товщину затверділого шару $\delta_{у т} / R_{\text {зв }}$ для кожного моменту часу;

- визначено відносний об'єм затверділого шару для кожного моменту часу;

- розраховано реальну товщину затверділого шару для кожного моменту часу.

Розрахунковий об'єм виливка - це його внутрішня частина (від внутрішнього діаметра до термічного центра), яка контактує із стрижнем (див. рис. 1). Аналогічний об'єм можна розглядати і з боку ливарної форми, адже фронти кристалізації сходяться якраз у термічному центрі. Для товстостінного виливка внутрішній діаметр розрахункового об'єму 50 мм, зовнішній (середина товщини стінки виливка) - 150 мм. Для тонкостінного виливка внутрішній діаметр 16 мм, а зовнішній - 20 мм. Висоту розрахункового елемента обох виливків прийнято за одиницю.

Розрахунковий об'єм товстостінного виливка:

$$
V=\frac{\pi}{4} \cdot\left(0,15^{2}-0,05^{2}\right) \cdot 1=0,0157 \text { б.од }
$$

Умовна товщина затверділого шару у момент часу $300 \mathrm{c}$ :

$$
\delta_{y T}=0,01177 \cdot \sqrt{(300-220)}=0,0105 \mu .
$$

Відносна товщина затверділого шару у момент часу $300 \mathrm{c}$ :

$$
\frac{\delta_{y T}}{R_{\text {зв }}}=\frac{0,0105}{0,05}=0,210 .
$$

Відносний об'єм затверділого шару:

$$
V_{300}=0,210 \cdot V=0,210 \cdot 0,0157=0,0033 \text { oб.oд. }
$$

Зовнішній діаметр затверділого шару $\mathrm{d}_{\mathrm{T}} \mathrm{i}$ його товщина $\delta_{\mathrm{T}}$ :

$$
\begin{aligned}
& \frac{\pi}{4} \cdot\left(d_{T}^{2}-0,05^{2}\right) \cdot 1=V_{300} ; \\
& d_{T}=\sqrt{\frac{4 \cdot V_{300}}{\pi}+0,05^{2}}=\sqrt{\frac{4 \cdot 0,0033}{3,14}+0,05^{2}}=0,082 \mathrm{~N} . \\
& \delta_{T}=\frac{d_{T}-0,05}{2}=\frac{0,082-0,05}{2}=0,016 \mathrm{M} .
\end{aligned}
$$

Як бачимо, реальна товщина затверділого шару відрізняється від умовної у більшу сторону. Відповідно, з іншого боку виливка (з боку форми) товщина затверділого шару буде відрізнятися у меншу сторону.

Проведено аналогічні розрахунки для моментів часу 500, 1000, 1500, 2000 і 2024 с. До цього додамо, що решту простору виливка (обмежену діаметрами $\mathrm{d}_{\mathrm{T}}$ i 150 мм) займає рідка зона. Усі результати занесено до табл. 1.

Розрахунки за аналогічним алгоритмом проведено і для тонкостінного виливка в моменти часу 0,$5 ; 1,0 ; 1,5 ; 2,0 ; 2,5 ; 3,0$ і 3,5 с. Всі результати занесено до табл. 2.

\section{Аналітичний розрахунок теплових полів у} виливках.

Зміну температури поверхні виливків поки що визначено лише до досягнення температури солідусу. Після цього моменту (220 с для товстостінного і 3,5 с для тонкостінного виливка) температура поверхні невідома. Закон її зміни та конкретні значення необхідно встановити.

Це потребує набагато більшої кількості даних, ніж ми маємо. Для отримання додаткової інфрормації визначимо зміну температури в центрах виливків протягом усього часу їх твердіння.

Відомо, що в момент часу т = 0 температура в центрі $\mathrm{T}_{ц}=\mathrm{T}_{\text {зал }}=1873 \mathrm{~K}$, а у момент завершення твердіння там зникає остання частка рідкої фрази, тобто досягається солідус: $\mathrm{T}_{ц}=\mathrm{T}_{\mathrm{c}}=1720 \mathrm{~K}$. Зміну температури у центрі виливка з достатньою точністю можна розрахувати за фрормулою С. Шварца $[2,3]$ :

$$
T_{\text {L }}=T_{\text {зал }}-\left(T_{\text {зал }}-T_{0}\right) \cdot \frac{1-\operatorname{erf}\left(\frac{y}{2 \cdot \sqrt{a_{p} \cdot \tau}}\right)}{1-\operatorname{erf}\left(\frac{K}{2 \cdot \sqrt{a_{p}}}\right)},
$$

те $\mathrm{T}_{ц}$ - температура у центрі виливка, який знаходиться на відстані у від поверхні, в момент часу т, К; Т - температура кристалізації сплаву, К; $a_{p}$ - коефіцієнт температуропровідності сплаву у рідкому стані, м²/c; К - коефіцієнт твердіння, $\frac{M}{c^{1 / 2}}$. 


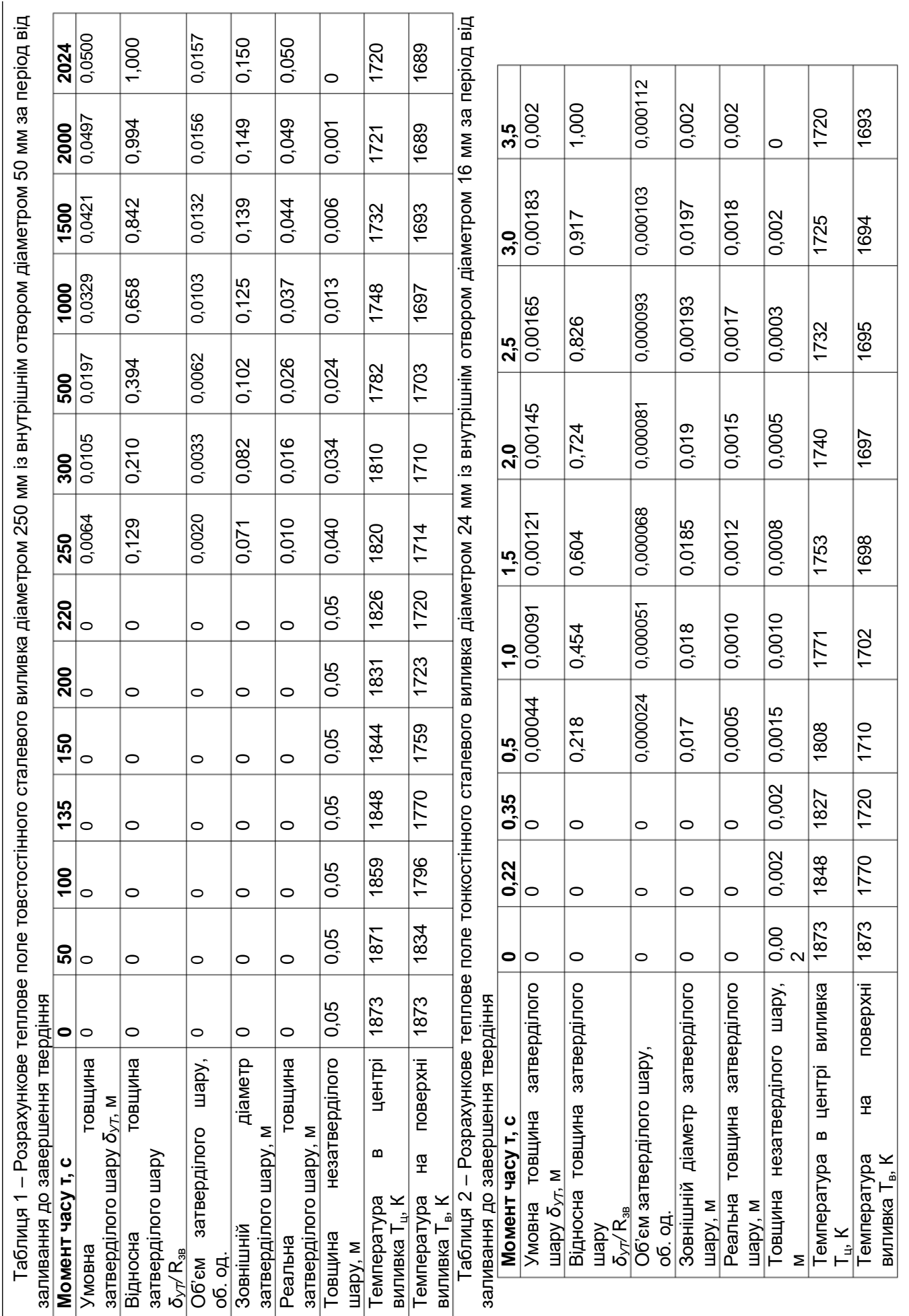

Для визначення коефіцієнта К, який

забезпечить точні результати в подальшому, врахуємо, що умовою повного затвердіння виливка $€$ досягнення у центрі температури солідусу (1720 К). Отже, у формулі (6) буде $\mathrm{T}_{ц}=\mathrm{T}_{\mathrm{c}} ; \mathrm{T}_{0}=\mathrm{T}_{\mathrm{c}}$.

Для товстостінного виливка $\mathrm{y}=0,05$ м. У такому разі отримаємо:

$$
1-\operatorname{erf}\left(\frac{0,05}{2 \cdot \sqrt{a_{p} \cdot \tau}}\right)=1-\operatorname{erf}\left(\frac{K}{2 \cdot \sqrt{a_{p}}}\right),
$$

$$
\frac{0,05}{2 \cdot \sqrt{a_{p} \cdot \tau}}=\frac{K}{2 \cdot \sqrt{a_{p}}} .
$$

Підставивши $\mathrm{T}=\mathrm{T}_{\mathrm{T}}=2024$ с, визначимо коефіцієнт твердіння К:

$$
K=\frac{R_{3 в}}{\sqrt{\tau_{T}}}=\frac{0,05}{\sqrt{2024}}=0,0011 \frac{M}{c^{1 / 2}} .
$$

і далі: 
Для тонкостінного виливка $\mathrm{y}=0,002 \mathrm{~m}, \mathrm{~T}_{\mathrm{T}}=3,5$ c. У такому разі:

$$
K=\frac{R_{3 в}}{\sqrt{\tau_{T}}}=\frac{0,002}{\sqrt{3,5}}=0,0011 \frac{M}{c^{1 / 2}} .
$$

За формулою (6) розраховано значення температури в центрі товстостінного виливка у моменти часу $50,100,150,200,250,300,500,1000,1500$, $2000 \mathrm{c}$, а також у моменти тпер $=135 \mathrm{c} ; \mathrm{T}_{\mathrm{c}}=220 \mathrm{c} \mathrm{i} \mathrm{\textrm {T } _ { \mathrm { T } }}$ $=2024$ с. Усі отримані результати занесено до табл. 1.

Також за формулою (6) розраховано температуру в центрі тонкостінного виливка у моменти чаcy 0,$5 ; 1,0 ; 1,5 ; 2,0 ; 2,5 ; 3,0$ c, а також у моменти $\mathrm{T}_{\text {пер }}=0,22 \mathrm{c} ; \mathrm{T}_{\mathrm{c}}=0,35 \mathrm{c} \mathrm{i} \mathrm{T}_{\mathrm{T}}=3,5 \mathrm{c}$. Усі отримані результати занесено до табл. 2.

Тепер у фіксовані моменти часу відомі значення температури в центрі виливків та положення фронту твердіння. Розділивши умовно виливок на рідку і тверду частини і розглядаючи його як двошарову стінку, коректним буде припущення, що теплові потоки у цих частинах будуть рівними [1]: $q_{T}=q_{P}$, а тому:

$$
\frac{\lambda_{P}}{\delta_{P}} \cdot\left(T_{L}-T_{C}\right)=\frac{\lambda_{T}}{\delta_{T}} \cdot\left(T_{C}-T_{B}\right)
$$

де $\lambda_{\mathrm{p}} \mathrm{i} \lambda_{\mathrm{T}}$ - коефріцієнти теплопровідності сплаву у рідкому і твердому стані, Вт/(м - К); $\delta_{p}$ і $\delta_{\mathrm{T}}-$ товщина рідкого та затверділого шару, м; $T_{ц}$ - температура у центрі виливка, К; $T_{C}$ - температура солідусу, К; Т В - температура поверхні виливка, К.
Із цього рівняння температура поверхні виливка:

$$
T_{B}=T_{C}-\frac{\lambda_{P} \cdot \delta_{T}}{\delta_{P} \cdot \lambda_{T}} \cdot\left(T_{L}-T_{C}\right) .
$$

Для врахування циліндричності виливка замість співвідношення товщини твердого і рідкого шарів потрібно врахувати співвідношення їх об'ємів:

$$
T_{B}=T_{C}-\frac{\lambda_{P} \cdot V_{T}}{V_{P} \cdot \lambda_{T}} \cdot\left(T_{L}-T_{C}\right)
$$

За попередньо обчисленими значеннями об'ємів твердого та рідкого шарів у різні моменти часу визначено температуру поверхні.

Наприклад, для товстостінного виливка у момент т $=250 \mathrm{c}$ :

$$
T_{B}=1720-\frac{23,3 \cdot 0,0020}{54,5 \cdot(0,0157-0,0020)} \cdot(1820-1720)=1714 K .
$$

Для тонкостінного виливка у момент т $=0,5 \mathrm{c}$ :

$$
T_{B}=1720-\frac{23,3 \cdot 0,000024}{54,5 \cdot(0,000112-0,000024)} \cdot(1808-1720)=1710 \mathrm{~K} \text {. }
$$

Розраховані температурні поля виливків наведено на рис. 2 і 3.

Перепад температур по перерізу виливків у процесі твердіння зменшується. Оскільки наприкінці твердіння він $є$ мінімальним, то в процесі подальшого охолодження у фоормі ним можна знехтувати і вважати температуру по перерізу виливка практично однаковою.

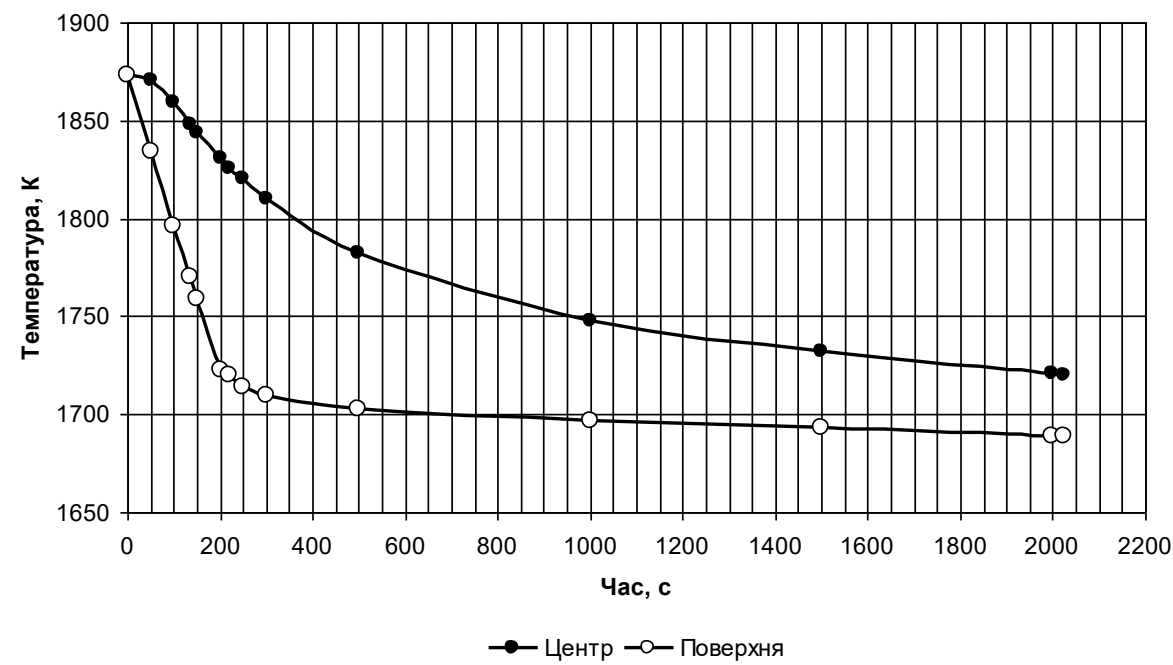

Рисунок 2 - Розподіл температур у товстостінному (100 мм) сталевому виливку (рис. 1, а) за період від заливання до повного твердіння 


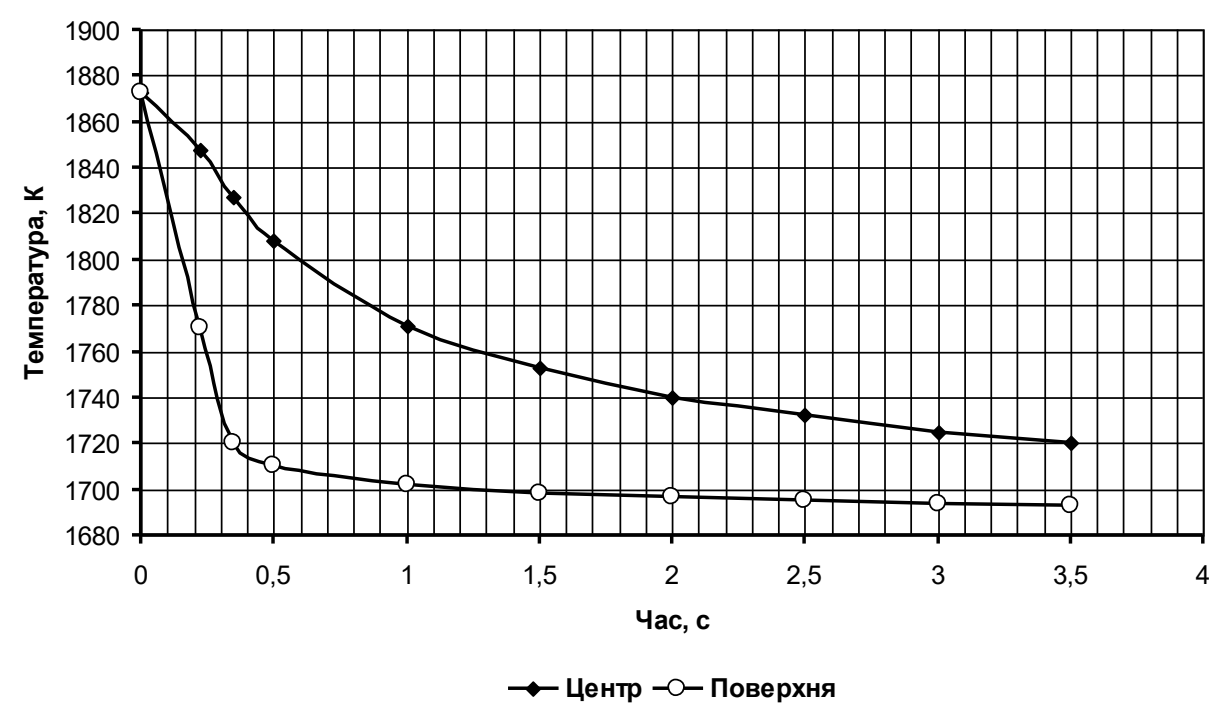

Рисунок 3 - Розподіл температур у тонкостінному (4 мм) сталевому виливку (рис. 1, б) за період від заливання до повного твердіння

\section{Висновки:}

1. Створено систему математичних методів для розрахунку теплових полів литих деталей у процесі їх кристалізації. Система базується на поєднанні раніше відомих аналітичних формул і власними розробок та не містить емпіричних коефіцієнтів і спрощень.

2. Вперше запропоновано методику та представлено математичні формули для визначення динаміки зміни температури поверхні виливка в інтервалі від заливання до солідусу.
3. Розроблено математичний метод розрахунку динаміки просування фрронту твердіння по перерізу виливка з урахуванням його конфігурації.

4. Створено методику розрахунку розподілу теплових полів у затверділій і рідкій частинах виливка.

5. За розробленими методами визначено теплові поля сталевих виливків із товщиною стінок 100 мм і 4 мм протягом періоду їх затвердіння у піщаній ливарній формі.

\section{Бібліографічний опис}

1. Вопросы теории литейных процессов / [П. Н. Аксенов, П. П. Берг, Н. М. Бодашков и др.]. - Москва: Машгиз, 1960. - 696 с.

2. Гуляев Б. Б. Теория литейных процессов / Б. Б. Гуляев. - Ленинград: Машиностроение (Ленингр. отд.), 1976. - 216 с.

3. Теоретичні основи ливарного виробництва / [В. Г. Могилатенко, О. І. Пономаренко, В. М. Дробязко та ін.]. - Харків: НТУ «ХПІ», 2011. - 288 с.

4. Баландин Г. Ф. Теория фрормирования оливки / Г. Ф. Баландин. - Москва: МГТУ им. Н.Э. Баумана, 1988. - Ч. $1-360$ c.

5. Saito S. Science Reports / S. Saito // Tohoku Imperial University. - 1921. - №10. - C. 305.

6. Ващенко К. И. Теоретические основы литейной технологии / К. И. Ващенко. - Київ: Вища школа, 1981. - 317 с.

7. Вейник А. И. Расчет отливки / А. И. Вейник. - Москва: Машиностроение, 1964. - 404 с.

8. Новиков П. Г. Температурное поле плоской стенки при изменении агрегатного состояния / П. Г. Новиков // Труды МТИПП / П. Г. Новиков. - Москва: Госэнергоиздат, 1957.

9. Инженерные расчеты по теории литейных процессов / [С. В. Инкин, И. Ф. Мазолов, М. В. Пикунов и др.]. - Алма-Ата: Рауан, 1991. - 224 с.

10. Огородникова О. Литейные CAE-системы AFSolid и WinCast / О. Огородникова, В. Черменский // САПР и графика. - 2001. - №8.

11. Dhodare A. S. Review on Interfacial Heat Transfer Coefficient During Solidification in Casting / A. S. Dhodare, P. M. Ravanan, N. A. Dodiya // International Journal of Engineering Research \& Technology (IJERT). - 2017. - №2. - C. 464-467. DOI:10.17577/IJERTV6IS020300.

12. Prediction of thermal field dynamics of mould in casting using artificial neural networks / F.Susac, V. Tăbăcaru, N. Baroiu, V. Păunoiu // MATEC Web of Conferences. - 2018. - №178. - C. 1-6. https://doi.org/10.1051/matecconf/201817806012.

13. Rajaraman R. Interfacial heat transfer coefficient estimation during solidification of rectangular aluminum alloy casting using two different inverse methods / R. Rajaraman, A. Gowsalya, R. Velraj // Frontiers in Heat and Mass Transfer (FHMT). - 2018. - №11. http://dx.doi.org/10.5098/hmt.11.23. 
14. Rafique M. Modeling and Simulation of Heat Transfer Phenomenon Related to Mold Heating during Investment Casting / M. Rafique, U. Shah // Engineering. - 2020. - №12. - C. 291-314. DOI: 10.4236/eng.2020.125024.

15. Марширов В. В. Численное on-line моделирование процесса затвердевания отливок / В. В. Марширов, Л. Е. Марширова // Литейное производство. - 2015. - №9. - С. 31-34.

16. Идрис Г. Г. Компьютерно-интегрированное проектирование литых поршней / Г. Г. Идрис, О. В. Акимов, А. П. Марченко // Литейное производство. - 2016. - №5. - С. 33-37.

17. Skočilasová B. Effect of mold material on temperature distribution in alloy cast / B. Skočilasová, J. Skočilas // AIP Conference Proceedings. - 2016. - №1768. https://doi.org/10.1063/1.4963039.

18. Бахтиаров Р.А., Воробьева Л.А. Практическое использование тепловых расчетов в металлургических процессах: Обзорная информация. - Москва: ЦНИИ информации и техникоэкономических исследований цветной металлургии, 1977. - 72 с.

\section{References}

1. Voprosy teorii litejnyh processov / [P. N. Aksenov, P. P. Berg, N. M. Bodashkov i dr.]. - Moskva: Mashgiz, 1960. - $696 \mathrm{~s}$.

2. Gulyaev B. B. Teoriya litejnyh processov / B. B. Gulyaev. - Leningrad: Mashinostroenie (Le-ningr. otd.), 1976. $-216 \mathrm{~s}$.

3. Teoretichni osnovi livarnogo virobnictva / [V. G. Mogilatenko, O. I. Ponomarenko, V. M. Dro-byazko ta in.]. - Harkiv: NTU «HPI», 2011. - 288 s.

4. Balandin G. F. Teoriya formirovaniya olivki / G. F. Balandin. - Moskva: MGTU im. N.E. Bau-mana, 1988. - CH. $1-360 \mathrm{~s}$.

5. Saito S. Science Reports / S. Saito // Tohoku Imperial University. - 1921. - №10. - S. 305.

6. Vashchenko K. I. Teoreticheskie osnovy litejnoj tekhnologii / K. I. Vashchenko. - Kiïv: Vishcha shko-la, 1981. - $317 \mathrm{~s}$.

7. Vejnik A. I. Raschet otlivki / A. I. Vejnik. - Moskva: Mashinostroenie, 1964. - $404 \mathrm{~s}$.

8. Novikov P. G. Temperaturnoe pole ploskoj stenki pri izmenenii agregatnogo sostoyaniya / P. G. Novikov // Trudy MTIPP / P. G. Novikov. - Moskva: Gosenergoizdat, 1957.

9. Inzhenernye raschety po teorii litejnyh processov / [S. V. Inkin, I. F. Mazolov, M. V. Piku-nov i dr.]. Alma-Ata: Rauan, 1991. - $224 \mathrm{~s}$.

10. Ogorodnikova O. Litejnye SAE-sistemy AFSolid i WinCast / O. Ogorodnikova, V. CHermenskij // SAPR i grafika. - 2001. - №8.

11. Dhodare A. S. Review on Interfacial Heat Transfer Coefficient During Solidification in Casting / A. S. Dhodare, P. M. Ravanan, N. A. Dodiya // International Journal of Engineering Research \& Technolo-gy (IJERT). - 2017. - №2. - S. 464-467. DOI:10.17577/JJERTV6IS020300.

12. Prediction of thermal field dynamics of mould in casting using artificial neural networks / F.Susac, V. Tăbăcaru, N. Baroiu, V. Păunoiu // MATEC Web of Conferences. - 2018. - №178. - S. 1-6. https://doi.org/10.1051/matecconf/201817806012.

13. Rajaraman R. Interfacial heat transfer coefficient estimation during solidification of rectangular aluminum alloy casting using two different inverse methods / R. Rajaraman, A. Gowsalya, R. Velraj // Frontiers in Heat and Mass Transfer (FHMT). - 2018. - №11. http://dx.doi.org/10.5098/hmt.11.23.

14. Rafique M. Modeling and Simulation of Heat Transfer Phenomenon Related to Mold Heating during Investment Casting / M. Rafique, U. Shah // Engineering. - 2020. - №12. - S. 291-314. DOI: 10.4236/eng.2020.125024.

15. Marshirov V. V. CHislennoe on-line modelirovanie processa zatverdevaniya otlivok / V. V. Ma-rshirov, L. E. Marshirova // Litejnoe proizvodstvo. - 2015. - №9. - S. 31-34.

16. Idris G. G. Komp'yuterno-integrirovannoe proektirovanie lityh porshnej / G. G. Idris, O. V. Akimov, A. P. Marchenko // Litejnoe proizvodstvo. - 2016. - №5. - S. 33-37.

17. Skočilasová V. Effect of mold material on temperature distribution in alloy cast / V. Skočilasová, J. Skočilas // AIP Conference Proceedings. - 2016. - №1768. https://doi.org/10.1063/1.4963039.

18. Bahtiarov R.A., Vorob'eva L.A. Prakticheskoe ispol'zovanie teplovyh raschetov $v$ metallur-gicheskih processah: Obzornaya informaciya. - Moskva: CNII informacii i tekhniko-ekonomicheskih issledovanij cvetnoj metallurgii, 1977. $-72 \mathrm{~s}$. 